\title{
Stock Market Response during COVID-19 Lockdown Period in India: An Event Study
}

\author{
Mohammad Noor ALAM', Md. Shabbir ALAM ${ }^{2}$, Kavita CHAVALI ${ }^{3}$ \\ Received: May 03, 2020 Revised: May 17, 2020 Accepted: June 07, 2020
}

\begin{abstract}
The research investigates the impact of the lockdown period caused by the COVID-19 to the stock market of India. The study examines the extent of the influence of the lockdown on the Indian stock market and whether the market reaction would be the same in pre- and post-lockdown period caused by COVID-19. Market Model Event study methodology is used. A sample of 31 companies listed on Bombay Stock Exchange (BSE) are selected at random for the purpose of the study. The sample period taken for the study is 35 days ( 24 February-17 April, 2020). An event window of 35 days was taken with 20 days prior to the event and 15 days during the event. The event (t1) being the official announcement of the lockdown. The results indicate that the market reacted positively with significantly positive Average Abnormal Returns during the present lockdown period, and investors anticipated the lockdown and reacted positively, whereas in the pre-lockdown period investors panicked and it was reflected in negative AAR. The study finds evidence of a positive AR around the present lockdown period and confirms that lockdown had a positive impact on the stock market performance of stocks till the situation improves in the Indian context.
\end{abstract}

Keywords : COVID-19, Event study, Lockdown period, Stock Market, Abnormal Return

JEL Classification Code : E2, E6, E44, E49

\section{Introduction}

The outbreak of coronavirus has caused a pandemic of the respiratory disease (COVID-19) for which vaccines and targeted therapeutics for treatment are unavailable (Wang et al. 2020). The pandemic caused major concern for public health as well as the economy of the world. The COVID-19 is the acronym used for Corona Virus Disease 2019. This

${ }^{1}$ First Author. Assistant Professor, Department of Accounting, College of Commerce and Business Administration, Dhofar University, Sultanate of Oman. Email: malam@du.edu.om

${ }^{2}$ Corresponding Author. Assistant Professor, Department of Finance \& Economics, College of Commerce and Business Administration, Dhofar University, Sultanate of Oman [Postal Address: P.O Box 2509, Salalah, Sultanate of Oman, 211] Email: shabbir.alam28@gmail.com

${ }^{3}$ Associate Professor, Department of Finance \& Economics, College of Commerce and Business Administration, Dhofar University, Sultanate of Oman. Email: kchavali@du.edu.om

(c) Copyright: The Author(s)

This is an Open Access article distributed under the terms of the Creative Commons Attribution Non-Commercial License (http://Creativecommons.org/licenses/by-nc/4.0/) which permits unrestricted noncommercial use, distribution, and reproduction in any medium, provided the original work is properly cited. virus causes a pneumonia of unknown cause first detected in Wuhan, China, and first reported to the World Health Organization (WHO) on 31st December, 2019. The World Health Organization announced the official designation of this deadly virus on February 11, 2020. On March 11, it declared COVID-19 a pandemic, pointing to over 118,000 cases of the coronavirus illness in 110 countries and territories around the world and the sustained risk of further global spread.(Time 2020).

India is the country with the second largest population in the world. As per World Bank data, India is home to 176 million poor people and also has lowest ranks in cleanliness and medical facilities all over the world, and it will become a disaster if COVID-19 is spreading to its population. But India was not far behind, and the first case was reported on 30 January, 2020; by 17 April 2020, 14,376 people died (Deccan Herald 2020). Without better standards of living and public health, it was major concern for the Government of India under Prime Minister Narendra Modi, who announced and ordered a nationwide lockdown for 21 days on 24th March, 2020 for preventing the spreading of the virus, and on 14 April, the Prime Minister extended the nationwide lockdown until 3 May. 
This Pandemic COVID-19 affected the economies of the world and India was also among those nations. Due to the lockdown ordered by the government of India, everything came to halt in this busiest country. The crashing of the global market economy, major drop in oil prices, and increasing unemployment are some of the impacts of the pandemic COVID-19 that affected almost all countries in the world. India was also not far behind to get the impact of COVID-19 on their economic growth, development, economy and stock market.

India has a robust stock market that reacts and responds well to the global situation. The first case was reported in India on 30th January and the lockdown ordered on 24 March, 2020, that was a gap of almost 53 days that was also a matter of concern; what if the Government had ordered the lockdown earlier? It may have slowed the spreading of the virus in the population. How did the stock market respond to this nationwide lockdown? In this event study, the influence of the lockdown due to COVID-19 on the stock market is explained with the semi-strong form of market efficiency hypothesis (Fama, 1970). They are called event studies (Fama, 1991). This event study measured how rapidly security prices respond to announcements of the lockdown due to COVID-19.

According to semi-strong Efficient Market Hypothesis, current market prices not only reflect information about historical prices of stocks, but also reflect information, which is publicly available. In semi-strong form of market efficiency, there can be some lag time before the price fully reflects all available information. This time lag can vary depending on the market, on the individual security, and the way in which information is shared. The present study attempts to gather evidence in support (if any) of the semi-strong form of EMH in the Indian stock market. (Foster, 2012). The authors of this study made an effort to examine the impact of the lockdown on the stock market and its effect on the Average Abnormal Return of various stocks.

\section{Literature Review}

Since, the COVID-19 was declared pandemic by WHO, there is a dearth of studies related to COVID-19 impact on stock market, as it is a new global development. Some research has been carried out to analyze the impact of COVID-19 on different economies, but the number is still small.

Ramelli and Wagner (2020) examine the market reactions to the COVID-19 on the international trade and financial policies of the firm and found a negative consequence for internationally-oriented US firms, especially those with China exposure and the US; markets moved feverishly when the virus spread across Europe and the US. The author concluded how the health crisis caused the economic crisis that amplified through various financial channels.

Adda (2016) attempted to address some issue related to the economic activity and spread of viral diseases, issues like the unintended consequences of economic activity on the spread of infections and how to allocate the limited resources to limit the spread of the infections, and used quasi-experimental variation to evaluate the importance of the police, ordered by the government to reduce interpersonal contact and closure of public transport networks, and found that it reduced the disease, but this measure is not costeffective and results are also showing that this spreading of infection is sensitive to economic conditions.

Hang (2016) investigates the underlying dynamics of share market bubbles in China during the recent decade and finds hindrance in the information caused large volatilities in the Chinese share market. Blockage of information prevents the shares to respond to economic conditions as well as external shocks and it increases or decreases the demand for shares when the supply is difficult to adjust. Information also has the effect on the performances of the stock market of India; good news or information have a positive impact on the trading of shares and inflows, whereas bad news or information have a negative impact that causes the high volatility which results in heavy outflows in the market

Nguyen and Pham (2018) examine the relationship between search-based sentiment and Vietnamese stock market returns. The author concluded that the sentimentinduced effect is mainly driven by pessimism. And optimistic investors seem to delay taking their investment action until the market corrects itself. The author didn't found any statistical evidence that optimism affects the market returns, but it provides a foundation to their claim that optimistic group may be potential investors who search with the intention to participate in the markets. Again information plays a key role for more participation of the new investors in the market that ultimately affects the stock returns

Lee and Brahmasrene (2018) investigate the relationship between the macroeconomic variables and stock price of Korea in the short run as well as the long run and found the evidence of long-run equilibrium relationship between selected macroeconomic variables such as money supply, industrial production index, inflation, exchange rates and interest rates and Korean stock market, whereas, money supply and short-term interest rate are not related to stock prices in the short-run. However, exchange rate is positively related to stock prices in the short-run. The author also found that there is no compelling evidence that the external shocks such as regional or global financial crisis have an impact on the stock price dynamics in the Korean stock market.

Gormsen and Koijen (2020) used the high frequency data on dividend futures to evaluate the impact growth expectations. Due to the COVID-19 lockdown in Italy, the 
Mohammad Noor ALAM, Md. Shabbir ALAM, Kavita CHAVALI /

Journal of Asian Finance, Economics and Business Vol 7 No 7 (2020) 131 - 137

dividend and GDP growth showed downward trend in US and European countries and also found in the short run, the lower bound on dividend growth is as severe as during the Global Crisis of 2008.

Baker et al. (2020) analyzed the role of COVID-19 developments in recent stock market behavior and compared with previous virus outbreaks. The author draw a comparison between Bird Flu, SARS, Swine Flu (H1N1), Ebola and MERS, and COVID-19.The author concluded that no previous infectious disease episode led to daily stock-market swings that even remotely resemble the response in the past month to COVID-19 developments.

Ozili and Arun (2020) analyze the impact of COVID-19 on the global economy; the period of the study started from the beginning of 2020 to March when COVID-19 spread to most of the countries. The study used the major policies of the government like fiscal monetary policy, public health measure, and restrictive measures that were adopted during the period of the study. The empirical investigation used by the author to find the impact of the social distancing policies on the economic activities and stock market indices of the country found that restriction on internal movement and higher fiscal policy spending had a positive impact on the level of economic activities, although the increasing number of confirmed coronavirus cases did not have a significant effect on the level of economic activities.

\section{Research Methods and Materials}

A sample of 31 companies are selected at random. The data related to stock prices are taken from Bombay Stock Exchange (BSE, https://www.bseindia.com/). The time period selected for the study was March-April 2020. The BSE 30 index closing prices for the respective period are taken. The event date is defined as the day the lockdown was announced and ordered on 24th March, 2020, which is taken as t1. This approach assumes that the information was known to the market on the event day. During the pre- and present lockdown period, the stock price of a total of 35 days are taken 20 days prior to the event day, event day (t1) and 15 days during lockdown.

In this research study, the market model event study methodology has been employed to measure the effect of the lockdown period due to COVID-19 on the stock market and prices. The market model used by Fama et al. (1969) assumes a linear relationship between the returns of the security to the returns of the market portfolio. This model has been chosen because it is powerful in detecting abnormal returns when compared to other elaborate methodologies like index model, and it is also free from criticisms of capital asset pricing model. The reason for using this model is because it has been proven to yield valid results (Salamudin et al., 1999). Market model methodology is a relatively powerful methodology applicable under a wide variety of situations (Brown and Warner 1985).

Estimation period and Event window: An estimation period and event window is selected to develop the market model. The study conducted uses daily prices of 35 trading days for pre- and present lockdown period that are included in the estimation period for computation of the regression coefficients for the sample companies. A 35-day event window, $t-20$ to $t+15$ in the pre- and present lockdown period where event date (t1) is the announcement of the lockdown period for computing the abnormal returns (AR), for each of the stocks, the average abnormal returns (AAR) of the sample of 31 companies and the cumulative average abnormal returns (CAAR) around the date of stocks in the sample. A comparison of pre-lockdown, and present lockdown period $\mathrm{AAR} \%$ returns and $\mathrm{T}$ statistics are calculated and compared.

The study undertakes to determine any significant positive AR associated with the lockdown period around the event dates and the speed with which the information relating to lockdown announcements is absorbed into the security prices in the market. The study examines the extent of influence of the lockdown period due to COVID-19 on the Indian stock market and the impact on the market sentiments between pre- and present lockdown period.

Hypothesis (H0): There is a significant positive AAR around the event date (Lockdown announcement date) and is significantly greater than zero i.e., $1 / \mathrm{n} . \Sigma \mathrm{AR} \geq 0$, where $\mathrm{n}$ is the number of companies in the sample selected.

Hypothesis (H1): There is a significant negative AAR around the event date (Lockdown announcement date) and is significantly less than zero, i.e., $1 / n . \Sigma A R<0$.

Table 1 shows the list of sample companies taken from BSE to test the impact of lockdown due to COVID-19 on stock market.

Table 2 shows the calculated regression coefficients $\alpha$ and $\beta$ values of the sample companies of pre-lockdown and present lockdown period (24th Feb to 17th March, 2020).

\section{Results and Discussion}

Table 3 presents results for each of the 35 days' event window, 20 days pre-lockdown period and 15 days present lockdown period for the entire sample of 31 companies. Table 3 reports the average daily AR, AARs, CARs and CAAR for the day's $t-20$ to $t+15$ along with the test statistics obtained using the MS Excel descriptive analysis tool for testing the null hypothesis. The AARs are negative on the day's t-20, $\mathrm{t}-18, \mathrm{t}-16, \mathrm{t}-15, \mathrm{t}-11, \mathrm{t}-10, \mathrm{t}-9, \mathrm{t}-8, \mathrm{t}-6, \mathrm{t}-3, \mathrm{t} 1, \mathrm{t} 2, \mathrm{t} 3, \mathrm{t} 13, \mathrm{t} 15$.

However, it is observed that there are significantly positive AARs on most of the present lockdown days. CAAR is also seen to be significantly positive in the event window. This 
Table 1: List of sample companies

\begin{tabular}{|c|c|}
\hline Company Name & Industry \\
\hline Lupin Ltd & Pharmaceutical \\
\hline Wipro Ltd & Pharmaceutical \\
\hline Tata Steel Ltd & Manufacturing \\
\hline Tata Motors Ltd & Automobile \\
\hline Tata Motors DVR Ordinary & Manufacturing \\
\hline Tata Consultancy Services Ltd & Information Technology \\
\hline Sun Pharmaceutical India Ltd & Healthcare \\
\hline State Bank of India & Banking \\
\hline Power Grid Corporation & Power \\
\hline ONGC Ltd & Oil \& Gas \\
\hline NTPC Ltd & Power \\
\hline Maruti Suzuki Ltd & Automobile \\
\hline Mahindra \& Mahindra Ltd & Automobile \\
\hline L\&T Ltd & Manufacturing \\
\hline Kotak Mahindra Bank Ltd & Banking \\
\hline ITC Ltd & FMCG \\
\hline Infosys Ltd & Information Technology \\
\hline Cipla & Healthcare \\
\hline ICICI Bank Ltd & Banking \\
\hline HDFC & Finance \\
\hline Hindustan Unilever Ltd & FMCG \\
\hline Hero Motor Corp & Automobile \\
\hline HDFC Bank Ltd & Banking \\
\hline Dr Reddy Labs Ltd & Healthcare \\
\hline Coal India Ltd & Mining \\
\hline Bharti Airtel Ltd & Telecom \\
\hline Bajaj Auto Ltd & Automobiles \\
\hline AXIS Bank & Banking \\
\hline Asian Paints Ltd & Manufacturing \\
\hline Adani Ports \& SEZ Ltd & Infrastructure \\
\hline Reliance Industries & Oil \& Gas \\
\hline
\end{tabular}

leads to acceptance of the null hypothesis (H0). It indicates that lockdown announcements and the returns of the stocks did boost the majority of the stocks in the sample. This may be due to the reaction of the lockdown announcement news because it was anticipated that the lockdown could control the spreading of the virus in the country that will ultimately benefit the country's stock market in long run and almost every country before India announced the lockdown.
Table 2: Firm characteristics regression coefficients using market model

\begin{tabular}{|c|c|c|}
\hline \multirow[t]{2}{*}{ Company Name } & \multicolumn{2}{|c|}{$\begin{array}{l}\text { Pre Lockdown and Present } \\
\text { Lockdown period (24th Feb to } \\
\text { 17th March, 2020) }\end{array}$} \\
\hline & $\alpha$ & $\beta$ \\
\hline Lupin Ltd & 0.008393801 & 0.430295965 \\
\hline Wipro Ltd & -0.00240028 & 0.697868215 \\
\hline Tata Steel Ltd & -0.00365065 & 1.001630387 \\
\hline Tata Motors Ltd & -0.01328619 & 0.906675019 \\
\hline $\begin{array}{l}\text { Tata Motors DVR } \\
\text { Ordinary }\end{array}$ & -0.01076237 & 0.681703754 \\
\hline $\begin{array}{l}\text { Tata Consultancy } \\
\text { Service }\end{array}$ & 0.001172035 & 0.818227267 \\
\hline $\begin{array}{l}\text { Sun Pharmaceutical } \\
\text { India }\end{array}$ & 0.009503926 & 0.758268722 \\
\hline State Bank of India & -0.006923398 & 1.012034032 \\
\hline $\begin{array}{l}\text { Power Grid } \\
\text { Corporation }\end{array}$ & 0.001149636 & 0.593451158 \\
\hline ONGC Ltd & 0.000903881 & 1.077431592 \\
\hline NTPC Ltd & 0.00070596 & 0.674922361 \\
\hline Maruti Suzuki Ltd & 0.003717096 & 1.161319515 \\
\hline $\begin{array}{l}\text { Mahindra \& Mahindra } \\
\text { Ltd }\end{array}$ & -0.002439501 & 0.975081832 \\
\hline L\&T Ltd & -0.00156827 & 0.947016231 \\
\hline $\begin{array}{l}\text { Kotak Mahindra Bank } \\
\text { Ltd }\end{array}$ & -0.001739842 & 1.038641173 \\
\hline ITC Ltd & 0.00298767 & 0.706615628 \\
\hline Infosys Ltd & 0.000393143 & 0.912294388 \\
\hline Cipla & 0.014033869 & 0.601589971 \\
\hline ICICI Bank Ltd & -0.000149552 & 1.299675272 \\
\hline HDFC & -0.000705451 & 1.143413602 \\
\hline Hindustan Unilever Ltd & 0.007865115 & 0.776937787 \\
\hline Hero Motor Corp & 0.001683657 & 0.919299897 \\
\hline HDFC Bank Ltd & -0.00043878 & 1.004163436 \\
\hline Dr Reddy Labs Ltd & 0.010362508 & 0.642452201 \\
\hline Coal India Ltd & -0.00127041 & 0.476301007 \\
\hline Bharti Airtel Ltd & 0.00497442 & 0.940483015 \\
\hline Bajaj Auto Ltd & -0.000590903 & 0.850022184 \\
\hline AXIS Bank & 0.000803705 & 1.531902944 \\
\hline Asian Paints Ltd & 0.004401631 & 0.756561753 \\
\hline Adani Ports \& SEZ Ltd & -0.002156406 & 0.859511045 \\
\hline Reliance Industries & 0.004376481 & 1.232632662 \\
\hline
\end{tabular}


Table 3: Daily Average AR and t statistics of Pre-Lockdown and Present Lockdown period (24th Feb to 17th March, 2020) as per Market Model

\begin{tabular}{|c|c|c|c|c|c|}
\hline Day $t$ & AAR\% & T stat & Null hypothesis test & CAR\% & CAAR $\%$ \\
\hline-20 & -63.321 & -2.4168 & Reject Ho & -19.62 & -63.32 \\
\hline-19 & -5.371 & -0.2945 & Can't Reject Ho & -1.66 & -68.69 \\
\hline-18 & -22.897 & -1.1822 & Can't Reject Ho & -7.09 & -28.26 \\
\hline-17 & 2.347 & 0.1027 & Can't Reject Ho & 0.72 & -20.54 \\
\hline-16 & -58.143 & -1.2709 & Can't Reject Ho & -18.02 & -55.79 \\
\hline-15 & -47.375 & -1.6983 & Reject Ho & -14.68 & -105.5 \\
\hline-14 & 97.997 & 2.2100 & Can't Reject Ho & 30.37 & 50.62 \\
\hline-13 & 62.436 & 1.6201 & Can't Reject Ho & 19.35 & 160.43 \\
\hline-12 & 7.101 & 0.3558 & Can't Reject Ho & 2.201 & 69.537 \\
\hline-11 & -34.098 & -0.8408 & Can't Reject Ho & -10.57 & -26.99 \\
\hline-10 & -47.436 & -0.8696 & Can't Reject Ho & -14.70 & -81.53 \\
\hline-9 & -62.646 & -1.2293 & Can't Reject Ho & -19.42 & -110.0 \\
\hline-8 & -22.465 & -0.4345 & Can't Reject Ho & -6.96 & -85.11 \\
\hline-7 & 2.577 & 0.04257 & Can't Reject Ho & 0.79 & -19.88 \\
\hline-6 & -36.265 & -0.7951 & Can't Reject Ho & -11.24 & -33.68 \\
\hline-5 & 80.827 & 1.4641 & Can't Reject Ho & 25.05 & 44.56 \\
\hline-4 & 65.874 & 0.8670 & Can't Reject Ho & 20.42 & 146.70 \\
\hline-3 & -53.706 & -0.6007 & Can't Reject Ho & -16.64 & 12.168 \\
\hline-2 & 69.282 & 0.8243 & Can't Reject Ho & 21.47 & 15.57 \\
\hline-1 & 20.450 & 0.3384 & Can't Reject Ho & 6.33 & 89.73 \\
\hline 1 & -33.404 & -0.4238 & Can't Reject Ho & -10.35 & -12.95 \\
\hline 2 & -161.007 & -2.2736 & Reject Ho & -49.91 & -194.4 \\
\hline 3 & -55.613 & -0.8149 & Can't Reject Ho & -17.24 & -216.6 \\
\hline 4 & 41.589 & 0.7208 & Can't Reject Ho & 12.89 & -14.02 \\
\hline 5 & 97.147 & 1.5461 & Can't Reject Ho & 30.11 & 138.73 \\
\hline 6 & 20.964 & 0.4361 & Can't Reject Ho & 6.49 & 118.11 \\
\hline 7 & 26.358 & 0.6799 & Can't Reject Ho & 8.17 & 47.32 \\
\hline 8 & 122.157 & 1.4083 & Can't Reject Ho & 37.86 & 148.51 \\
\hline 9 & 23.544 & 0.3154 & Can't Reject Ho & 7.29 & 145.70 \\
\hline 10 & 78.420 & 2.1300 & Can't Reject Ho & 24.31 & 101.96 \\
\hline 11 & 196.610 & 2.2902 & Can't Reject Ho & 60.94 & 275.03 \\
\hline 12 & 126.666 & 2.2751 & Can't Reject Ho & 39.26 & 323.27 \\
\hline 13 & -11.936 & -0.2585 & Can't Reject Ho & -3.70 & 114.72 \\
\hline 14 & 18.0349 & 0.4758 & Can't Reject Ho & 5.59 & 6.098 \\
\hline 15 & -32.125 & -0.6409 & Can't Reject Ho & -9.95 & -14.09 \\
\hline
\end{tabular}


Table 4: Comparison of AAR across pre-lockdown and present lockdown period

\begin{tabular}{|l|c|c|c|c|}
\hline \multicolumn{5}{|c|}{ Pre-lockdown and present lockdown period, 2020 } \\
\hline \multicolumn{1}{|c|}{ Event window } & AAR\% & T stat & Null hypothesis test & Significance \\
\hline Pre-Lockdown Phase & -0.004 & -0.170 & Reject Ho & $*$ \\
\hline Present Lockdown Phase & 0.045 & 2.311 & Can't Reject Ho & - \\
\hline
\end{tabular}

* Significant at $5 \%$ level of significance

And growth and development of any stock market depend upon the strong economy of the country and this COVID-19 is a major hindrance in the overall growth of the economy. Policymakers, analysts, and stock market players have taken the news of the lockdown positively and welcomed the decision of the government that was ultimately reflected on the response of stock market indices.

Table 4 shows the comparison of AAR across different event windows for the pre- and present lockdown period. In the pre-lockdown phase, the stock market reaction $\mathrm{H} 0$ was rejected at 5-percent level of significance, but during the present lockdown period the AAR was positive and, thus, $\mathrm{H} 0$ is accepted. This could be probably because the stock market anticipated the lockdown announcement by the Government and expected that it will be better for the country. And investors were also waiting for the Government to imposed the lockdown for preventing the spreading of COVID-19 and benefits the country in the long run; this the reason there is positive AAR during the present lockdown period.

The AAR in the present lockdown stage was positive probably because the people wanted the Government to impose the lockdown to stop the virus from spreading and the reaction is shown in the returns of stock market. But in the pre-lockdown period, the AAR was negative and $\mathrm{H} 0$ is rejected. This is due to the panic all over the world. Heavy withdrawals from the stock market and FIIs outflow contributed in the negative AAR, and investors were waiting for the policy formulation of protective measures to prevent the spread of COVID-19 like the lockdown. Due to the global market reaction, in the pre-lockdown period in India, investors engaging in heavy withdrawal and selling of the stock reflected in a negative AAR in pre-lockdown period days.

\section{Conclusions}

The COVID-19 pandemic has affected the global economy of which India is a big participant. India is the country with the second largest population in the world, so the pandemic is especially dangerous for India. The COVID-19 affected almost all stock markets around the world. The world stopped due to the virus outbreak and it pushed the world into the great crisis of the century. The total lockdown and social distancing is the only solution for preventing the spreading of the virus until a vaccine is available. India also announced the lockdown as a protective measure, but India announced a little bit late and this is evident through the pre-lockdown period where AAR was negative. The announcement of the lockdown was taken positively by the stock market that was reflected in the stock market response; this is not an ideal situation, but still there is a chance when the lockdown is lifted and COVID-19 is eradicated from the country, the stock market will recover.

The study finds the evidence of a positive AR around the present lockdown period and confirms that the lockdown has a positive impact on the stock market performance until the situation improves in the Indian context. However, the result holds true for the select sample of BSE-listed companies and during the period considered for the study. It cannot be generalized for other traded stocks, nor in other periods in the future or in a different market environment. The implications of this study are that investors can take precautionary steps before trading in stocks during the period of a lockdown. Risk averse investors can avoid trading around the lockdown to avoid the risk linked with volatility of stocks in the lockdown period. The result of this study will benefit investors as it may help them better understand and evaluate the impact of the lockdown on stock markets caused by COVID 19.

\section{References}

Adda, J. (2016). Economic activity and the spread of viral diseases: Evidence from high frequency data. The Quarterly Journal of Economics, 131(2), 891-941. DOI: doi.org/10.1093/qje/ qjw005

Baker, S. R., Bloom, N., Davis, S., Kost, K., Sammon, M., \& Viratyosin, T. (2020). The Unprecedented Stock-Market Reaction to COVID-19, KelloggInsight. Chicago, IL: Kellogg School of Management, Northwestern University.

Brown, S. J., \& Warner, J. B. (1985). Using daily stock returns: The case of event studies. Journal of Financial Economics, 14, 3-31.

DH Web Desk (2020). Coronavirus India update: State-wise total number of confirmed cases, deaths on April 17. Deccanherald Online Newspaper, Retrieved April 20, 2020, https://www. deccanherald.com/national/coronavirus-india-updatestate-wise-total-number-of-confirmed-cases-deaths-onapril-17-826340.html 
Mohammad Noor ALAM, Md. Shabbir ALAM, Kavita CHAVALI /

Ducharme, J (2020) World Health Organization Declares COVID-19 a 'Pandemic.' Here's What That Means. Time Online Newspaper, Retrieved April 20, 2020, from https:// time.com/5791661/who-coronavirus-pandemic-declaration/ March 11

Fama, E. F. (1970). Efficient capital markets: a review of theory and empirical work. The Journal of Finance, 2, 383-417.

Fama, E. F. (1991). Efficient capital markets II. The Journal of Finance, 46, 1575-1618.

Fama, E. F., Fisher, L., Jensen, M. C., \& Roll, R. (1969). The adjustment of stock prices to new information. International Economic Review, 10(1), 1-21.

Foster, L. (2012). Does the US Presidential Election Impact the Stock Market? CFA Institute Web.

Gormsen, N. J., \& Koijen, R. (2020). Coronavirus: Impact on Stock Prices and Growth Expectations. VOX, CEPR Policy Portal. https://voxeu.org/article/coronavirus-impact-stock-prices-andgrowth-expectations

Hong, H. (2016). Information Cascade and Share Market Volatility: A Chinese Perspective. Journal of Asian Finance, Economics and Business, 3(4), 17-24, https://doi.org/10.13106/jafeb.2016. vol3.no4.17
Lee, J. W., \& Brahmasrene, T. (2018). An Exploration of Dynamical Relationships between Macroeconomic Variables and Stock Prices in Korea. Journal of Asian Finance, Economics and Business, 5(3), 7-17. http://doi.org/10.13106/jafeb.2018.vol5.no3.7

Nguyen, D. D., \& Pham, M. C. (2018). Search-based Sentiment and Stock Market Reactions: An Empirical Evidence in Vietnam. Journal of Asian Finance, Economics and Business, 5(4), 4556. http://doi.org/10.13106/jafeb.2018.vol5.no4.45

Ozili, P., \& Arun, T. (2020). Spillover of COVID-19: Impact on the Global Economy, SSRN Electronic Journal. DOI: doi. org/10.2139/ssrn.3562570

Ramelli, S., \& Wagner, A. F. (2020). Feverish Stock Price Reactions to COVID-19, Swiss Finance Institute Research Paper No. 2012. DOI: doi.org/10.2139/ssrn.3550274

Salamudin, N., Ariff, M., \& Nassir, A.M. (1999). Economic influence on rights issue announcement behaviour in Malaysia. Pacific-Basin Finance Journal, 7(3), 405-427.

Wang, C, Li, W., Drabek, D., Okba, N. M. A., van Haperen, R., Osterhaus, A. D. M. E., van Kuppeveld, F. J. M., Haagmans, B. L., Grosveld, F., \& Bosch, B. (2020). A human monoclonal antibody blocking SARS-CoV-2 infection. BioRaxiv, DOI: doi. org/10.1101/2020.03.11.987958 